\title{
Haruniye Alman Yetimhanesi
}

\author{
Muttalip Şimşek*
}

(ORCID ID: 0000-0003-1184-2345)

Makale Gönderim Tarihi

29.03.2019
Makale Kabul Tarihi

12.09.2019

\section{Özet}

19. Yüzyılın sonlarına doğru meydana gelen Ermeni olayları, sonuçları itibariyle misyon kuruluşları için büyük bir fırsat olmuş ve bu kuruluşlar Doğu bölgelerinde bir biri ardına istasyon açmışlardı. 1909 yılında Adana ve çevresinde vukû bulan olaylar da misyon teşkilatları için yeni bir çalışma alanı ortaya çıkardı ve Alman misyonerler, Adana Vilayeti dâhilinde bulunan Bahçe Kazası'na bağlı Haruniye Karyesi'nde açtıkları yetimhane ile bölgede faaliyete başladılar.

Haruniye Alman Yetimhanesi'nin kurulmasında önemli bir yere sahip olan Alman Yardım Birliği (Deutscher Hülfsbund für Christliches Liebeswerk in Orient), 1890 'ı yıllarda Maraş, Mamuretülaziz ve Van gibi bölgelerde tesis ettiği birimler ve buralardaki faaliyetleri sayesinde misyon açısından başarılı çalışmalar yapmıştı. Yardım Birliği başta yetimhaneler olmak üzere, sağlık birimleri, dul kadınlar için bakım evleri ve atölyeler açmak suretiyle faaliyet bölgelerinde etkili bir misyon çalışması yürütmeye muvaffak oldu.

Bu çalışmada, Alman Yardım Birliği'nin önemli istasyonlarından birisini oluşturan Haruniye Alman Yetimhanesi, ağırııkı olarak o dönem istasyonlarda görev yapan misyonerlerin kaleme aldığı notlar ve bu konuya ışık tutan diğer telif eserler (Almanca) ile Osmanlı Arşivi belgeleri ışı̆ı̆ında değerlendirilecektir. Burada evvelâ, yetimhanenin kuruluş süreci ve bu istikâmette misyonerlerin Osmanlı makamlarıyla yaptığı yazışmalar ortaya konacaktır. Daha sonra, Osmanlı Devleti için kritik bir dönemi ifade eden Birinci Dünya Savaşı öncesi ve savaş yıllarında yetimhanenin durumu ve çalışmaları hakkında bilgi verilecektir. Son olarak, savaşın bitmesiyle birlikte yetimhanede kalan çocukların akıbeti ve kurumun Amerikan yardım kuruluşu Yakın Doğu Yardım Komistesi (Near East Relief)'ne nasıl devredildiği izah edilecektir.

Anahtar Kelimeler: Alman Yardım Birliği, Haruniye, Yetimhane, Protestan Misyonerliği.

*Dr., Öğretmen (MEB), mutsimsek@gmail.com.

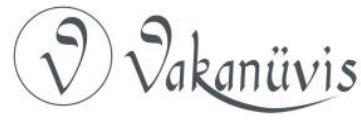




\section{Harunıye German Orphanage}

\section{Abstract}

The Armenian events that took place towards the end of the 19th century were a great opportunity for the mission organizations due to their results and they had opened one station in the eastern regions. The events in Adana and its surroundings in 1909 also created a new working area for mission organizations and German missionaries started to operate in the region with the orphanage they opened in Haruniye Subdistrict which is subject to the Bahçe Township (Adana Province).

The German Relief Organisation (Deutscher Hülfsbund für Christliches Liebeswerk in Orient), which has an important place in the establishment of the German Orphanage, in the 1890s, Maraş, Mamuretülaziz and Van in the area of the establishment of the units and work here in terms of the mission had made successful work. The Relief Organisation was able to carry out an effective mission in the regions of operation by opening orphan homes, health units, nursing homes and workshops for widows.

In this study, the Haruniye German Orphanage which is one of the important stations of the German Relief Organisation, predominantly the notes written by the missionaries working at the stations in that period and other copyrighted works (German) and the Ottoman Archive documents will be evaluated. Firstly, the establishment of the orphanage and in this direction the correspondence of the missionaries with the Ottoman authorities will be revealed. Then, information about the status and activities of the orphanage will be given before the First World War and during the years of war, which is a critical period for the Ottoman Empire. Finally, with the end of the war, the fate of the children who remain in the orphanage and how the organization has been transferred to the Near East Relief, the American aid organization, will be explained.

Keywords: German Relief Organisation, Haruniye, Orphanage, Protestant Missionary.

\section{Giriş}

Alman Protestan misyonerliğinin Osmanlı topraklarında faaliyet yürüten önemli temsilcilerinden birisi de "Doğu'da Hıristiyan Şefkati için Alman Yardım Birliği ${ }^{1}$ (Deutscher Hülfsbund für Christliches

\footnotetext{
${ }^{1}$ Bundan sonra bu kuruluş için sadece "Yardım Birliği" tabiri kullanılacaktır.
}

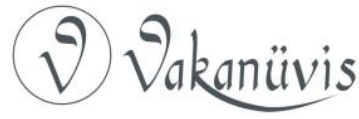


Liebeswerk in Orient)"dir. Harput başta olmak üzere Maraş, Van ve Muş gibi Ermeni nüfusunun yoğun olarak yaşadığı bölgeleri faaliyet alanı olarak seçen Yardım Birliği, özellikle 19. yüzyılın sonlarından itibaren meydana gelen Ermeni olaylarını bahane ederek bölgede sistemli bir faaliyet yürütmüştü. Osmanlı-Alman ilişkilerinin de tesiriyle Doğu'da oldukça rahat bir çalışma imkanı bulan bu misyon kuruluşu için 1909 yılında Adana'da meydana gelen Ermeni olayları, bölgede yeni bir istasyon oluşturulmasının yolunu açmıştı. ${ }^{2}$

Bilindiği üzere, II. Meşrutiyet'in ilanı diğer milletlerde olduğu gibi, Ermeniler üzerinde de olumlu bir etkiye sahip olmuş, ancak bu iyimser hava çok geçmeden dağılmıştı. Ermeniler bağımsız bir devlet kurma hayali ile nüfus bakımından yoğun olarak yaşadıkları bölgelerde tekrar huzursuzluk çıkarmaya başladılar. Adana Vilayeti, Ermeniler'in yoğun olarak bulunduğu bir bölgeydi. 1909 yılının Nisan ayı ortalarında İstanbul'da meydana gelen huzursuzluk Adana ve çevresinde de etkisini gösterdi ve 14 Nisan gecesi Ohannes adındaki bir Ermeni'nin iki Türk'ü silahla vurması üzerine şehirde olayların fitili ateşlenmiş oldu. Zaten Adana Piskoposu Moşeg uzun süredir Ermenileri silahlanmaya teşvik ediyor ve onları yakında kurulacağını iddia ettiği "Kilikya Ermeni Krallığı" için şiddetli bir mücadeleye hazırlıyordu. ${ }^{3}$ Özellikle Taşnak Derneği marifetiyle tertip edilen ve kasıtı çıkarılan olaylarla Müslümanların aşırı reaksiyon göstermesini sağlayarak Batılı devletlerin Ermenileri koruma bahanesiyle askerî müdahalede bulunmaları amaçlanmıştı. Nisan ayı boyunca aralıklı olarak meydana gelen olaylar neticesinde 20 bine yakın insan (yaklaşık 17 bin Ermeni ve 1.850 Müslüman) hayatını kaybetmişti. ${ }^{4}$

\footnotetext{
2 Axel Meißner, Martin Rades "Christliche Welt" und Armenien, Bausteine für eine Internationale Ethik des Protestantismus, Lit Verlag, Berlin 2010, 206-207.

3 Salâhi R. Sonyel, "İngiliz Gizli Belgelerine Göre Adana'da Vuku Bulan Türk-Ermeni Olayları (Temmuz 1908-Aralık 1909)", Belleten, Cilt 51, Sayı 201 (1987), s. 1268-1270; Stanford J. Shaw, Birinci Dünya Savaşı'nda Osmanlı Imparatorluğu-Ermeniler, Çev: Şadi Dinlenç, TTK Yay., Ankara 2017, s. 6.

${ }^{4}$ Stanford J. Shaw and Ezen K. Shaw, History of the Ottoman Empire and Modern Turkey, Cambridge University Press, New York 1977, s. 281; Enver Ziya Karal, Osmanlı Tarihi, ikinci Meşrutiyet ve Birinci Dünya Savaşı, C. IX, TTK Yay., Ankara 1996, s. 95-96; Mehmed Asaf, 1909 Adana Ermeni Olayları ve Anılarım, Haz. İsmet Parmaksızoğlu, TTK Yay., Ankara 1986, s. 27-40. Meşrutiyet'in ilanıyla ülkede egemen olan iyimser hava bir süre sonra bozulmaya başladı. Ermeni komiteleri bu süreçte meydana gelen
}

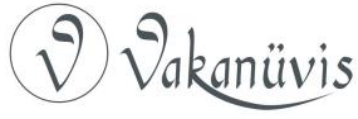


Bu olaylar neticesinde yetim kalan çocuklar ile eşlerini kaybeden dul kadınlar, misyon kuruluşları için hedef kitleyi oluşturuyordu. Büyük bir kısmı Gregoryan mezhebine mensup olan bu insanlara zor zamanlarında yardım etmek, onların Protestanlığa kazandırılması adına önemliydi. Dolayısıyla Adana ve çevresi de, bu olaylar sonrasında Yarım Birliği için uygun bir çalışma ortamına sahipti. Yardım Birliği Anadolu topraklarında 1897 yılında faaliyete başlamıştı ve özellikle II. Meşrutiyet'in ülkede oluşturduğu ortamı çalışma alanlarını genişletmek adına büyük bir fırsat olarak görüyordu. Bu dönem Osmanlı topraklarındaki çalışma şartları misyonerler tarafından Almanya'ya gönderilen mektuplarda "burada misyon çalışmaları için bütün kapılar açık" şeklinde ifade ediliyordu. Diğer taraftan misyon çevreleri, Sultan II. Abdülhamid'in tahttan indirilmesini de "gün doğumu (Sonnenaufgang)" olarak tarif etmişlerdi. ${ }^{5}$

Yardım Birliği'nin Anadolu'da yürüttüğg̈ faaliyetlerin ağırlık noktasını "yetim çalışmaları (Waisenwerk)" oluşturuyordu. Misyonun kurucusu Ernst Lohmann 1896 yılında Anadolu'ya yaptığı ilk keşif gezisini tamamlayıp Almanya'ya dönerken yanında birkaç Ermeni yetim çocuğu da götürmüştü. Birkaç ay sonra ikinci bir grup yetim daha Almanya'ya götürüldü ve bu çocuklar Alman bakıcı ailelerin yanına verildi. Çocukların bu şekilde Almanya'ya götürülerek bakımlarının sağlanması sürdürülebilir bir yöntem değildi. Böylece 1897 yılının ortalarında Mamuretülaziz (Elazığ)'de açılan ilk yetimhaneyi daha sonra Maraş, Van ve Muş'ta açılanlar takip etti. Yardım Birliği, 1908 yılında Anadolu'da toplam 20 yetimhanede, 1900 yetimin bakımını

Bulgaristan, Avusturya, Sırbistan, Girit isyanları ve iç karışıklıkları büyük bir fırsat olarak gördüler. Ermeniler, Çukurova'da bir isyan çıkarmaları halinde bölgeye yabancı müdahalenin olacağını, Batılı devletlerin Mersin Limanı'na asker çıkaracaklarını ve Kilikya bölgesinin Ermenilere verileceğini düşünüyorlardı. Gültekin Ural, Ermeni Dosyası, Kamer Yay., İstanbul 1998, s. 304.

${ }^{5}$ Uwe Feigel, Das Evangelische Deutschland und Armenien Die Armenierhilfe deutscher evangelischer Christien seit dem Ende des 19. Jahrhunderts im Kontext der deutschtürkischen Beziehungen, Vandenhoeck u. Ruprecht, Göttingen 1989, s. 141 vd.

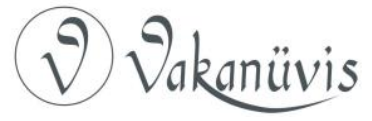


sağlıyordu. Ayrıca Amerikan istasyonlarında barınan 100 yetimin giderleri de Yardım Birliği tarafından karşılanıyordu. ${ }^{6}$

Adana'da meydana gelen olaylar Batı kamuoyunun dikkatlerini bu bölgeye çevirdi. Bölge Bağdat Demiryolu güzergâhında bulunması nedeniyle Almanlar için önemli bir yere sahipti. Yardım Birliği de bölgede yeni bir istasyon oluşturmak için çalışmalara başladı. Haruniye Yetimhanesi ${ }^{71}$ nin kuruluşuna giden yol da bu şekilde açılmışoldu.

\section{Adana'da Yetim Çalışmalarının Başlaması ve Haruniye Yetimhanesi'nin Açılması}

Adana'daki olaylar sona erince Yardım Birliği Maraş'ta görev yapan Paula Schäfer'ı bölgeye göndermişti. Bayan Schäfer bölgeden topladığı 200 Ermeni yetimi Maraş'a götürdüğü gibi, Almanya'daki misyon merkezine Adana ve çevresinde bakıma muhtaç yaklaşık 2 bin yetimin bulunduğunu bildirdi. Yardım Birliği bu haber üzerine destekçilerine yardım çağrısı yaptı ve kısa zamanda 10 bin Mark toplanarak bölgeye gönderildi. Ayrıca Urfa'da faaliyet yürüten bir diğer Alman misyoner kuruluşu Alman Doğu Misyonu da Adana için yapılan yardım çağrısına olumlu cevap verdi ve yaklaşık 50 yetim Urfa'ya götürüldü. Adana için en büyük yardım 100 bin Frank ile İsviçre'den geldi. Bu para ağırlıklı olarak yıkılan evlerin yeniden inşası ile yetim ve dul kadınların bakımı için kullanılacaktı. ${ }^{8}$

\footnotetext{
6 Johannes Ehmann, "Das Waisenwerk des Deutschen Hülfsbundes im Orient", 25 Jahre im Orient Ein Gang durch die Arbeit des Deutschen Hülfsbundes für christliches Liebeswerk im Orient, Verlag Orinet, Frankfurt a. M. 1921, s. 99-101.

7 Bilindiği üzere, Protestan misyonerlerinin Osmanlı topraklarındaki faaliyetlerine dair çalışmalar son zamanlarda bir artış göstermiştir. Bazı çalışmaların özellikle Alman misyon faaliyetlerine odaklandığı da görülmektedir. Oysa, Uğur İnan'ın "Osmanlı Devleti'nde Almanların Protestan Misyonerlik Faaliyetleri" adlı eseri dışında kaynaklarda Haruniye Yetimhanesi ile ilgili bilgiye rastlamak neredeyse mümkün değildir. Bu çalışma ile, Haruniye Yetimhanesi kurucularından B. von Dobbeler'in eşi Anna von Dobbeler tarafından tutulan notlar başta olmak üzere istasyonlarda görev yapan diğer misyonerlerin gözlemlerine ilk defa burada yer verilmiş; yetimhane ilgili etraflı bir değerlendirme ortaya konmaya çalışıımıştır.
}

8 Feigel, a.g.e., s. 145-147.

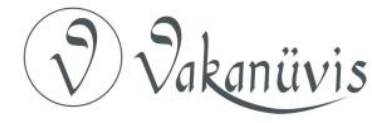


Bunların yanında, Alman Doktor Müller Lambert adlı misyoner 1909 yılının Ekim ayında Cebel-i Bereket Mutasarrıflığı' na müracaat ederek Haruniye ve Hasanbeyli'de yaşayan Ermeni yetimlerin bakımı ve eğitimleri için bir yetimhane inşa etme talebini iletmişti. Doktor Lambert başvuru dilekçesinde, eğer Osmanlı Hükûmeti'nin veya Ermeni Patrikliği'nin bölgede bir yetimhane açma planı varsa bu teşebbüsünden vazgeçeceğini belirtmişti. Her iki taraftan böyle bir teşebbüs olmayacaksa ve Osmanlı Hükûmeti de müsaade ederse, bölgede bir yetimhane açmak istediğini, bunun için hâlihazırda 1.200 liralık nakdî bir kaynaklarının bulunduğunu, 1.500 liranın da yine kullanılmak üzere yolda olduğunu ifade etmişti. Mutasarrıflık ise Dâhiliye Nezâreti'ne gönderdiği 31 Ekim 1909 tarihli yazıda, Alman Doktor Lambert'in daha evvel Antep ve Maraş'ta büyük yetimhaneler inşa ettiğini, Haruniye ve Hasanbeyli'de de yetimlerin bakımı ve eğitimleri için büyük bir yetimhane açmak istediğini, ancak bu talebe müsaade edilirse misyonerlerin yetimleri himaye görüntüsü altında çevirdikleri pek çok entrikanın önüne geçilemeyeceğini belirterek adı geçen şahsa verilecek izin hususunda daha dikkatli davranılması tavsiyesinde bulunmuştu. ${ }^{10}$

Doktor Lambert'in bu teşebbüsü neticesiz kalmıştı. Çevre bölgelerde bulunan istasyonlara buradaki yetimlerin taşınması da uzun vadeli bir çözüm değildi. Ermeni yetimlerin diğer istasyonlara götürülerek bakımlarının sağlanması bazı güçlükleri de beraberinde getiriyordu. Herşeyden önce bazı aileler çocuklarının uzak yerlere götürülmesine razı değildi. Ayrıca misyona ait diğer istasyonlarda bu yetimlerin de kabul edilebileceği kadar yer bulunmuyordu. Bu yüzden bölgede bir yetimhane açılması gerekiyordu. Yardım Birliği burada oluşturacağı istasyon için daha evvel Anadolu'da çalışmış, bölge insanını ve özellikle Ermenileri iyi tanıyan tecrübeli misyonerleri göndermesi gerekiyordu. Bu görev için Muş'ta beş yıl süreyle çalışan ve Muş istasyonunun kurulmasında büyük emeği olan Benno von Dobbeler ve eşi Anna von Dobbeler'i uygun buldu. Üstelik von

9 Yirminci yüzyılın başlarında Cebel-i Bereket Sancağı, Adana Vilayeti'nin beş sancağından (diğer dördü Adana merkez, Kozan, Mersin ve İçel) birisiydi. Haruniye ise, Cebel-i Bereket Sancağı'na bağlı Bahçe Kazası'nın bir karyesiydi. 1320 (1902) Adana Vilayet Salnamesi, Matbaa-i Vlâyet-i Adana, s. 130-198.

${ }^{10}$ Başbakanlık Osmanlı Arşivi (BOA), İrade Dâhiliye (i.DH), 1478/64, Lef. 2-5.

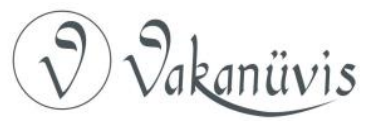


Dobbeler çiftinin hem yerel idarî makamlar, hem de bölgedeki Müslüman ahali ile yaşadığı problemler nedeniyle Muş'taki istasyondan alınarak başka bir yere gönderilmesi gerekiyordu. Bunun için en uygun yer Adana'nın Bahçe Kazası'na bağlı Haruniye Karyesi idi. ${ }^{11}$

Yetimhane neden Adana veya buraya bağlı büyük kaza merkezlerinde değil de, Haruniye gibi küçük bir yerleşim yerinde açılacaktı? Bunun en önemli sebebi, Haruniye'de bir Alman okulunun bulunmasıydı. Bu okul Bağdat Demiryolu'nun yapımında çalışan Alman görevlilerin çocuklarının eğitimleri için 1902 yılında açılmıştı. Demiryolu çalışanlarının Adana'daki işleri bitince de Alman Hükûmeti tarafından 1912 yılında Alman Yardım Birliği'ne devredildi. ${ }^{12}$ Ayrıca Haruniye'de belirli bir Protestan topluluğu vardı ve küçük bir yerleşim birimi olmasına rağmen Haruniye'de Protestanların kendilerine mahsus bir de kiliseleri bulunuyordu. ${ }^{13}$ Dolayısıyla Alman misyonerler için Haruniye, daha rahat hareket edebilecekleri bir bölge durumundaydı. Nitekim 1909 olaylarının hemen sonrasında Yardım Birliği'nin Maraş İstasyonu'ndan Johannes Storck Haruniye'ye gönderildi ve burada yeni bir istasyon kurmak için çalışmalara başladı. 1911 yılında da Yardım Birliği'nin Yönetim Kurulu Başkanı Friedrich Schuchardt çalışmaları yerinde görmek üzere Haruniye'yi ziyaret etti. Bu süreçte Ermeni yetimlerin bakımına kısmen de olsa başlanmıştı. ${ }^{14}$

Von Dobbeler çifti 1911 yılının sonlarına doğru Muş'tan ayrılarak Maraş üzerinden Haruniye'ye geldi ve onları karyenin girişinde yetim çocuklar karşıladı. Bu çocuklar iki yıldır Haruniye'deki Alman mektebi binasında kalıyordu. Von Dobbeler çifti Haruniye'ye gelince Johannes

\footnotetext{
${ }^{11}$ BOA, İrade Dosya Usulü (i.DUiт), 36/33 (1332/1916).

12 Uğur İnan, Osmanlı Devleti'nde Almanların Protestan Misyonerlik Faaliyetleri, TTK Yay., Ankara 2015, s. 501.

13 Haruniye'deki Protestanlara ait kilise Birinci Dünya Savaşı'nın son yıllarında çıkan bir yangında tamamen yanmış ve kilisenin yeniden inşası için Adliye ve Mezâhib Nezâreti'nden izin talebi olmuştu. BOA, Dâhiliye Nezâreti idare Evrakı (DH.ID), 144/44, 27 Şubat 1926 (1920). Kilisenin yeniden inşasına izin verildiğine dair Şûrâ-yı Devlet kararı için bkz. BOA, İrade Adliye ve Mezâhib (i.AZN), 105/30, 22 Şubat 1327 (1921). ${ }^{14}$ Belirtilen hususlar için bkz. 25 Jahre im Orient Ein Gang durch die Arbeit des Deutschen Hülfsbundes für christliches Liebeswerk im Orient, Verlag Orinet, Frankfurt a. M. 1921, s. 93.
}

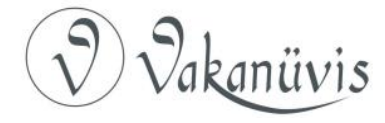


Storck buradaki çalışmaları bırakarak Maraş'a geri döndü. Artık yetim çalışmalarının daha planlı bir şekilde yürütülmesi gerekiyordu. Bunun için B. von Dobbeler daha evvel Alman okulu olarak kullanılan ve 3 katlı (35 odadan oluşan) binayı yetimhaneye çevirerek çalışmalara başladı. Yetimhaneye başlangıçta 80'i kız, 80'i erkek olmak üzere 160 çocuk alınmıştı. Von Dobbeler çifti Muş'ta görev yaptıkları süre zarfında Ermenice'yi iyi derecede öğrenmişler ve bölgedeki Ermenilerle rahat bir şekilde iletişim kurabilmişlerdi. Ancak Haruniye'de yaşayan Ermeniler Türkçe konuştuğundan (Maraş'ın bazı bölgelerinde de durum aynıydı) misyonerler için herşeyden önce bir dil sorunu ortaya çıkmıştı. Illerleyen yıllarda yetimhaneye o bölgede yaşayan Ermeni çalışanların alınması ile dil sorunu bir nebze de olsa aşıldı. ${ }^{15}$

\section{Yetimlerin Bakımı ve Eğitimi}

Yardım Birliği'ne ait yetimhanelerde ortalama 200 çocuğun bakımı sağlanırdı. Aynı durum Haruniye Alman Yetimhanesi için de geçerli idi. Nitekim yetimhanede kalan çocuk sayısı hiç bir zaman 200'ü geçmemişti. Çocuklar 20-25 kişilik gruplar halinde yatakhanelerde kalır ve başlarında bir oda sorumlusu bulunurdu. Genellikle Ermenilerden seçilen bu görevliler yetimlerin eğitimiyle ilgilenirlerdi. Eğitim çalışmalarında Alman misyonerler de aktif görev alırdı. Bu yüzden yetimhanalerde Alman-Doğu karışımı bir hâkimdi. ${ }^{16}$

1913 yılı istatistiğine göre, Yardım Birliği'nin Anadolu'da toplam 39 okulu vardı ve bu okullarda 109 öğretmen görev yapıyor, 3.361 öğrenci de eğitim alıyordu. Maraş, Harput ve Van gibi büyük istasyonlarda yetimlerin devam edebileceği birkaç okul varken Haruniye'de sadece bir okul bulunuyordu. Bu okula 190 öğrenci devam ediyordu ve çocukların eğitimi ile 6 öğretmen ilgileniyordu. Diğer Alman yetimhanelerinde Ermenice'nin yanında Almanca ve İngilizce de öğretilir, ancak ağırlık Ermenice'ye verilirdi. Haruniye Karyesi Bağdat Demiryolu güzergâhında olması nedeniyle okulda Almanca ${ }^{17}$

\footnotetext{
${ }^{15}$ Anna von Dobbeler, "Am Fuße des Amanusgebirges (Harunije)", 25 Jahre im Orient Ein Gang durch die Arbeit des Deutschen Hülfsbundes für christliches Liebeswerk im Orient, Verlag Orinet, Frankfurt a. M. 1921, s. 54.

${ }^{16}$ Ehmann, a.g.m., s. 101-104.

17 Benzer uygulama Alman Doğu Misyonu'nun en büyük istasyonu olan Urfa'daki yetimhaneye ait okulda da vardı. 1912'den itibaren İngilizce ve Süryanice müfredattan
}

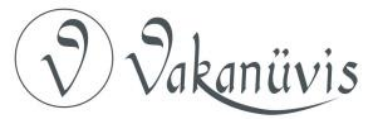


öğretimine daha fazla önem verilmiş ve ders planına da eklenmişti. Buradan çıkan öğrenciler bir üst okul olan Halep'teki Realschule'ye giderek eğitimlerine devam edebilirdi. Yetimhanede kalan çocukların Almanca öğrenmeleri özellikle Birinci Dünya Savaşı yıllarında bölgede bulunan Alman askerlerin işini kolaylaştırmış ve burada yetişen çocuklar onlara rehberlik yapmışlardı.

Yetimhanede çocuklara eğitim ilköğretim düzeyinde (Elementarunterricht) veriliyordu. Okuma, yazma ve hesap temel derslerdendi. Sınıf ilerledikçe derslerin içeriği değişiyordu. Akademik başarısı yüksek olan çocuklarla özel olarak ilgilenilir, başarılı olanlardan bazıları ileri tahsil için Almanya'ya gönderilirdi. ${ }^{18}$

Osmanlı sınırları içerisinde bulunan yabancı okullar ve yetimhaneler Maârif-i Umûmiye Nizamnâmesi'ne göre Maârif Nezâreti'nden bir ruhsat olmak zorundaydı. Yetimhane bünyesinde ibtidaî derecede bir mektep bulunuyordu. Ancak, 1915 yılına kadar bu mektep için herhangi bir ruhsat talebinde bulunulmamıştı. Bu yüzden mektebin kapatılması gündeme gelince misyonerler Maârif Nezâreti'ne başvurarak ruhsat talebinde bulundular. Alman Sefareti'nin de girişimiyle mektebin ibtidaî derecede olması ve Von Dobbeler'in mesul müdür olarak kabul edilmesi talep edilmişti. ${ }^{19}$ Meclis-i Vükelâ da Haruniye Yetimhanesi bünyesindeki mektebin ibtidaî derecede olmak ve Von Dobbeler müdür-i mesul tanınmak, kanun, nizam ve talimatlar ile daha evvel imzalanmış antlaşmalara bağlı kalmak şartıyla ruhsat verilmesini onaylamıştır. ${ }^{20}$ Alınan bu karar Dâhiliye Nâzırı Talat Paşa tarafından Adana Valisi Cevdet Bey'e gönderilen 10 Mayıs 1332 (23

kaldırılarak yerine, misyonerlerin ifadesiyle, "bu ülkede şimdiden çok aranan, ancak Bağdat Demiryolu sayesinde bu yörenin gelecekteki Avrupa diline dönüşecek olan" Almanca getirilmişti. Daha geniş bilgi için bkz: Richard Schäfer, Geschichte der Deutschen Orient-Mission, Missionshandlung und Verlag, Lepsius, Fleischmann und Grauer, Potsdam 1932, s. 62.

18 Ernst Sommer, "Erziehungsarbeit im Orient", 25 Jahre im Orient Ein Gang durch die Arbeit des Deutschen Hülfsbundes für christliches Liebeswerk im Orient, Verlag Orinet, Frankfurt a. M. 1921, s. 120-123. 1914 yılında kurumda çalışan personel sayısı 9'a yükselmişti. Adnan Şişman, XX. Yüzyılın Başlarında Osmanlı Devleti'nde Yabancı Devletlerin Kültürel ve Sosyal Müesseseleri, Atatürk Araştırma Merkezi Yayınları, Ankara 2006, s. 330.

${ }^{19}$ BOA, I.DUiT, 36/33, Lef. 2, 27 Mart 1332 (9 Nisan 1916).

${ }^{20}$ BOA, Meclis-i Vükela Mazbataları (MV), 242/100, 5 Mayıs 1332 (18 Mayıs 1916).

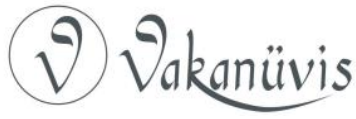


Mayıs 1916) tarihli bir takrir ile bildirilerek iktizasının icrası istenmiştir. $^{21}$

Haruniye Yetimhanesi'nde çocuklar için en ağır iş temizlik meselesiydi. Büyük çocuklar kaldıkları bölümlerin temizliğinden kendileri sorumluydu. Günlük bir saatlik ev işi esnasında (çok küçük çocuklar hariç) ana çalışma alanları temizleniyordu. Her sabah tekrarlanan bu temizlik çalışmasında çocuklara sadece ev temizliği değil, çevre temizliği de yaptırılıyordu. Mülkiyet bilinci kazandırmak için büyük çocukların her birine içinde çiçek veya sebze yetiştirebilecekleri küçük bir bahçenin bakımı verilirdi. ${ }^{22}$

Yetimhanede çocukların yaşam alanları düzenlenirken çoğu zaman Doğu'ya ait alışkanlıklara dikkat ediliyordu. Örneğin çocuklar masa ve sandalyelerde değil $20-25 \mathrm{~cm}$ yüksekliğe sahip alçak masalarda çömelerek yemek yerlerdi. Yatarken de yüksek bir karyola yerine yere serilen yataklarda uyuyabilecekleri bir düzen oluşturulmuştu. Oturma odalarında ise koltuk yerine boydan boya yastık döşenmiş ve ortada halı bulunan bir tefrişat tercih edilmişti. ${ }^{23}$

Alman yetimhanelerinde çocuklar 13-14 yaşına kadar en az bir alanda meslek eğitimi alırlardı. Bunun için her yetimhane bünyesinde muhakkak birkaç el işi atölyesi bulunurdu. Örneğin, marangozluk, kunduracılık, demircilik ve dokumacılık gibi alanların birinde veya tarım alanlarında beceri sahibi olurlardı. Haruniye Yetimhanesi'nde çocukların dikiş, halı dokuma ve iplik eğirme eğitimi alabilecekleri atölyeler vardı. Burada üretilen ürünlerin bir kısmı pazarlarda satılır ve az da olsa bir gelir elde edilirdi. Bu birimlerin dışında revir,

\footnotetext{
21 "Bahçe Kasabası'nda kâin Haruniye nâm Alman Eytamhane mektebinin Almanya Devleti Fehîmesi tarafından Von Dobbeler müdür-ü mesul tanınmak ve ibtidaî derecede olmak ve mekâtib-i husûsiyeye dair kavanîn ve nizamât ve ta'limât ile uhûd-ı atîkanın elfası üzerine müsesesât-ı ecnebiye hakkında ittihazı takarrur eden muâmelâtı havî ta'limâtın mekâtib-i husûsi ahkâmına ittiba' edilmek şartıyla ruhsat-ı resmiyeye rabtı hususuna bi'l-isti'zan irâde-i seniyye-i hazret-i padişâhi şeref mütea'llık buyrularak Maârif Nezâret-i Celilesine tebliğat icra kılındığı bâ-tezkire-i seniyye izbâr kılınmıştır ol babda." BOA, Dâhiliye Nezâreti İdare-i Umûmiye Evrakı (DH.i.UM), 70/20.

22 A. von Dobbeler, a.g.m., s. 60.

${ }^{23}$ Ehmann, a.g.m., s. 106-107.
}

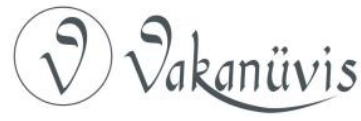


çamaşırhane ve mutfakta da çocuklara görev verilir, onların hayata hazırlanmaları ve sorumluluk almaları sağlanırdı. ${ }^{24}$

Çocuklar akademik eğitimin yanında kabiliyetlerine bağlı olarak bir enstrümanı kullanabilecekleri şekilde eğitim alırlardı. Daha çok keman çalma becerisi kazanan çocuklar, 18 yaşına gelip de yetimhaneden ayrıldıktan sonra düğünlerde bu sanatlarını kullanarak para kazanabilirlerdi. Savaş yıllarında herhangi bir iş bulamayan yetimlerin bir kısmı Amerika'ya gitmiş ve sahip oldukları becerileri sayesinde iyi para kazanmışlardı. ${ }^{25}$

Yardım Birliği, yetimhanelerin giderlerini büyük oranda Almanya'da bulunan gönüllü bakıcı ailelerin bağışlarıyla karşılıyordu. Yönetim Kurulu daha fazla bağış yapılmasını sağlamak için yetimhanelerde kalan çocuklardan bakıcı gönüllü ailelere mektup yazmalarını isterdi. Çocuklar bu mektuplarda, bağış yapanları kendi anne/babaları gibi gördüklerini ve bu yardımlar sayesinde sıcak bir yuvalarının olduğunu ifade ederek onların bağış yapma duygularını canlı tutmaya çalışırlardı. ${ }^{26}$ Haruniye Yetimhanesi'nde kalan çocukların bütün işleriyle yakından ilgilenen Anna von Dobbeler de çocuklara sık sık mektup yazdırırdı. ${ }^{27}$

Alman Yardım Birliği diğer istasyonlarda yaygın olarak uyguladığı gibi, Haruniye'de de faaliyetlerini sadece yetimlerin bakımı ile sınırlandırmamış, sağlık hizmetleri ve dul kadınlara yönelik yardım çalışması da yürütmüştü. Sağlık çalışmalarında herşeyden önce yetimhanede kalan çocuklara öncelik verildiğinden bir bölgede istasyon açıı ıçılımaz oraya hemen bir hemşire gönderilirdi. B. von Dobbeler ve eşi Anna von Dobbeler büyük oranda yetimhanenin işleri ile ilgilenmişti. Onlara diğer işlerde, özellikle çocukların sağlık sorunları ve istasyondaki tıbbî misyonla ilgilenmesi için Yardım Birliği, Paula Schäfer'ı da göndermişti. ${ }^{28}$ Birinci Dünya Savaşı'nın sonlarına doğru sağlık birimlerinde daha fazla doktor ve hemşireye ihtiyaç

\footnotetext{
${ }^{24}$ A. von Dobbeler, a.g.m., s. 60.

25 Meißner, a.g.e., s. 307; Ehmann, a.g.m., s. 108.

${ }^{26}$ Hans-Lukas Kieser, Iskalanmış Barış Doğu Vilayetleri'nde Misyonerlik, Etnik Kimlik ve Devlet 1839-1938, Çev: Atilla Dirim, İletişim Yayınları, İstanbul 2010, s. 326.

${ }^{27}$ A. von Dobbeler, a.g.m., s. 63.

28 Inan, a.g.e., s. 502.
}

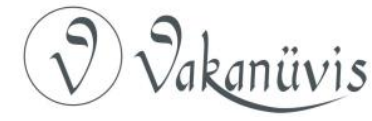


duyulduğundan Yardım Birliği Mamuretülaziz, Maraş ve Haruniye'ye sağlık personeli takviyesi yapmaya başladı. Ancak daha evvel istasyonlara rahat bir şekilde misyoner gönderen kurum, savaş nedeniyle bu hususta bazı zorluklarla karşılaşacaktır. Örneğin, hemşire Marie Wachhals ve Hedwig Seidler'i Haruniye'ye göndermek isteyen Yardım Birliği Osmanlı makamlarından uzun süre izin alamamıştı. Nitekim Hariciye Nezâreti aracılığıyla yapılan başvurulara, "Başkumandanlık tarafından uygun görülmediği" gerekçesiyle olumsuz cevap verilmişti. ${ }^{29}$ Ancak Alman Sefareti'nin ısrarlı talepleri neticesinde savaşın sonlarına doğru Başkumandanlık makamının müsaade etmesiyle Emniyet-i Umûmiye Müdürlüğü, Marie Wachhals ile Hedwig Seidler'e Adana Vilayeti dâhilinde yer alan Haruniye'de hastabakıcılık yapmak üzere izin verildiğini Alman Sefâreti'ne bildirmiş ve adı geçen misyonerler de Haruniye'ye gitmiştir. ${ }^{30}$

\section{Sıkıntılı Yıllar ve Yetimhanenin Kapanması}

Birinci Dünya Savaşı'na kadar Yardım Birliği bütün istasyonlarında hiç bir sorun yaşamadan faaliyetlerine devam etmişti. Ancak Birinci Dünya Savaşı'nın ilerleyen yıllarında sıkıntılar yaşanmaya başlandı. Bunlardan en önemlisi 1915 yılında çıkarılan tehcir yasasıydı. Yardım Birliği'nin yetimhanelerinde kalan çocukların neredeyse tamamı Ermeni idi ve bu karar, yetimhanelerin boşaltılması anlamına geliyordu. Tehcir kararının Haruniye'de de uygulanacağı ve yetimhanenin boşaltılacağı, çocukların yanında Ermeni öğretmen ve çalışanların da tehcire tabi tutulacağı duyumları üzerine $B$. von Dobbeler, tehcir kararının Haruniye'de uygulanmaması ricasını valiye iletmek üzere Adana'ya gitti. Valinin tehciri uygulama niyetinde olduğunu görünce Alman Sefareti'ne ve Yardım Birliği'nin Almanya'daki merkezine mektuplar yazarak yetimler ile Ermeni öğretmen ve çalışanların tehcirden muaf tutularak yerlerinde bırakılmaları yönünde Osmanlı makamlarına baskıda bulunmalarını istedi. B. von Dobbeler'in

\footnotetext{
${ }^{29}$ BOA, Hâriciye Nezâreti Siyasi (HR.SYS), 2438/34, 04.08.1917; Ayrıca Alman Sefâreti, bu tarihlerde Hâriciye Nezâreti'nden Muallime Frieda Lau adlı bir misyonerin de Haruniye'ye gitmesi için izin talebinde bulunmuştu. BOA, HR.SYS, 2436/61, 22.06.1917. Bu misyonere izin ancak 1918 yılının ortalarında verilmişti. BOA, Hâriciye Nezârei İdare (HR.iD), 83/106, 04.06.1918. ${ }^{30}$ BOA, HR.ID, 82/1, 24.04.1918.
}

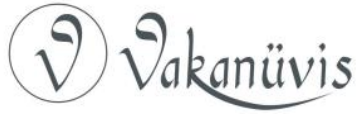


Adana'daki durumun kritik olduğu yönündeki mektubunu alan Yardım Birliği Merkez Komitesi Başkanı F. Schuchardt, Alman Sefareti'ne Haruniye'deki Ermenilerin yerlerinde bırakılmalarına yardımcı olmalarını rica eden bir mektup gönderdi. F. Schuchardt ayrıca, Anadolu'daki durumu yakından görmek ve zor durumda olan Ermenilere maddî yardımda bulunmak amacıyla Anadolu'ya gelmek için izin talebinde bulundu. Alman Dışişleri Bakanlığı, Merkez Komitesi Başkanı F. Schuchardt'a İstanbul'daki Alman Büyükelçiliği'nin Anadolu'daki Yardım Birliği'ne ait kurumların korunması ve Ermenilerin yerlerinde kalması hususunda büyük çaba sarfetmeye devam ettiğini, ancak Anadolu'ya seyahat etmek için uygun bir ortamın bulunmaması nedeniyle kendisine şimdilik izin verilmediğini bildirdi. ${ }^{31}$

Alman Büyükelçiliği'nin teşebbüsleri meyvesini kısa zamanda verdi ve Dâhiliye Nezâreti tarafından Adana Vilayeti'ne gönderilen şifre telgrafta, Haruniye Alman Yetimhanesi ile mektebin vilayet tarafından kapatılmak istendiğine dair Alman Sefareti aracılığıyla başvuruda bulunulduğ $u^{32}$ belirtilerek misyonerlerin idaresinde bulunan Haruniye Yetimhanesi'ndeki Ermeni çalışan ve çocuklara ilişilmemesi gerektiği ifade edilmişti. ${ }^{33}$

Tehcir kararıyla birlikte Osmanlı Devleti, sınırları içerisinde faaliyet gösteren yabancılara ait mektep, yetimhane ve diğer kurumları sıkı bir takibe almış ve vilayetlere gönderilen yazılarda yabancılara ait mektep ve yetimhanelerden ruhsatsız olanların derhal kapatılmasını istemişti. ${ }^{34}$ Bu süreçte Von Dobbeler, yukarıda da değinildiği üzere, derhal Maârif Nezâreti'ne başvurarak yetimhaneye bağlı mektebe ruhsat almıştı. Bununla birlikte, Dâhiliye Nezâreti tarafından Adana Vilayeti'ne gönderilen şifre telgraflarda Haruniye Yetimhanesi'ndeki Ermeni çalışan ve yetimlerine dokunulmaması yönündeki ısrarlı tembihleri 1915 yılının Ağustos ve Eylül ayları boyunca devam etmiştir. ${ }^{35}$ Netice itibariyle, Haruniye Yetimhanesi Alman Sefareti'nin girişimleri

\footnotetext{
31 İnan, a.g.e., s. 502-503.

32 BOA, Dâhiliye Nezâreti Şifre Kalemi (DH.ŞFR), 52/208.

${ }_{33} B O A$, DH.ŞFR, 55/43, 4 Ağustos 1331 (17 Ağustos 1915).

${ }^{34}$ BOA, DH.ŞFR, 55 A 155, 27 Ağustos 1331 (9 Eylül 1915).

35 BOA, DH.ŞFR, 484/72, 5 Ağustos 1331 (18 Ağustos 1915); DH.ŞFR, 56/91, 7 Ağustos 1331 (20 Ağustos 1915); DH.ŞFR, 56/157, 12 Ağustos 1331 (25 Ağustos 1915); DH.ŞFR, 491/21, 14 Eylül 1331 (27 Eylül 1915).
}

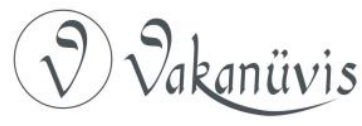


neticesinde kapatılmadığı gibi, burada bulunan Ermeni öğretmen, müstahdem ve çocuklar da yerlerinde kalmıştır.

Savaş yıllarında istasyonu takviye etmek isteyen Yardım Birliği, 1916 yılında Muş'taki istasyonun kapatılması üzerine Danimarkalı Bodil C. Biørn'u Haruniye Yetimhanesi'ne gönderdi. Biørn Haruniye'de bir yıl kaldı ve bu süre zarfında başhemşire olarak görev yaptı. ${ }^{36} 1918$ yılında Marie Wachhals ve Hedwig Seidler sağlık biriminde, öğretmen Frieda Lau ise eğitim biriminde görevlendirilmek üzere Haruniye'ye gönderildi. ${ }^{37}$

Savaş yıllarında yetimhanenin başka bir sorunu daha vardı. O da kurumun giderleri için gerekli finansal kaynağın Almanya'dan gönderilememesi idi. Yardım Birliği'nin bu yıllarda Haruniye Yetimhanesi'ne gönderdiği para neredeyse $1 / 3-1 / 5$ oranında azalmıştı. Savaş nedeniyle ürün tedarikinde zorluklar yaşandığı gibi enflasyonun etkisiyle ürünler pahalılaşmıştı. Yetimhanede çalışanlarla birlikte yaklaşık 200 kişi kalıyordu ve bunların iaşeleri için önemli miktarda gıdaya ihtiyaç vardı. Neyse ki, Osmanlı makamları bu ihtiyaca duyarsız kalmamış ve yetimhaneye Suriye'den buğday, mercimek ve patates göndermişti. ${ }^{38}$

Savaşın sonunda Mondros Mütarekesi'nin imzalanması ve Osmanlı topraklarında bulunan Alman ve Avusturya vatandaşlarının sınır dışı edilmesi kararının çıkarılmasıyla birlikte Yardım Birliği'ne ait istasyonlarda görev yapan misyonerlerin artık Anadolu'da barınmayacağı anlaşılmışı. Zaten yukarıda belirtilen maddî sıkıntılar nedeniyle yetimlerin bakımı da zorlaşmıştı. İşte bu noktada Amerikan yardım kuruluşu Near East Relief (Yakın Doğu Yardım Heyeti) devreye girdi ve Anadolu'daki yetimhanelerde kalan Ermeni çocukların Suriye topraklarına nakledilmesi için çalışma başlattı. NER, Suriye'nin dışında Yunanistan'da da yardım birimleri oluşturdu ve yaklaşık 500 bin

\footnotetext{
36 Inger Marie Okkenhaug, "Women on a Mission! Scandinavian Welfare and the Armanians in the Ottoman Empire, 1905-1917", Interpreting Welfare and Relief in the Middle East, Ed: Nefissa Naguib and Inger Marie Okkenhaug, Leiden-Boston 2008, s. 81.

3729 ve 30. dipnotlara bakınız.

${ }^{38}$ A. von Dobbeler, a.g.m., s. 58.
} 
yetişkin Ermeni ile 100 bin yetimin bakımını üstlendi. ${ }^{39}$ Misyonerler Haruniye Yetimhanesi'nde kalan çocukların bakımını Mondros Ateşkes Antlaşması'ndan sonra NER'in idaresine bıraktı. Alman misyonerler 1919 yılının Sonbahar aylarına kadar Haruniye'den ayrılmadılar. ${ }^{40}$ Ancak Fransız güçlerinin bölgeye gelişiyle Alman misyonerler bölgeyi terketti. Harput ve Maraş gibi büyük istasyonlarda bulunan yetimleri daha çok Suriye ve Lübnan topraklarında oluşturulan yardım birimlerine nakleden NER, Haruniye Yetimhanesi'nde kalan yetimleri 1920 yılında İngilizlerin kontrolünde bulunan Kıbrıs'a nakletti ve bu yetimlere İngiliz misyon kuruluşları bakmaya başladı. ${ }^{41}$ Böylece Haruniye'de 1909 Adana olayları sonrasında kısmen, 1912 yılından itibaren ise sistemli bir şekilde başlayan misyon çalışmaları 1920 yılında çocukların Kıbrıs'a götürülmesiyle sona ermiştir. ${ }^{42}$

\section{Sonuç}

Alman Yardım Birliği, 1909 Adana Olayları sonrasında oluşan olumsuz şartları fırsata çevirmek gayesiyle bölgede çalışmalara başlamış ve bu süreçte Haruniye'de bir yetimhane açmıştı. Yıllık bütçesinin yarıdan fazlasını yetim çalışmalarına ayıran ve faaliyetlerinin ağırık noktasını yetimlere yönelik çalışmalar oluşturan Yardım Birliği, 1912 yılında Haruniye Yetimhanesi'ni açmıştır. B. von Dobbeler ve eşi A. von Dobbeler gibi Ermeniler arasında uzun süre kalan ve misyon için önemli yere sahip olan misyonerleri Haruniye'ye göndererek burada oluşturlacak istasyona ne kadar değer verdiğini göstermiştir.

Adana Olayları neticesinde anne/babasını kaybeden yüzlerce Ermeni yetimin bakımını üstlenen kurum, Haruniye'nin Bağdat Demiryolu güzergâhında olması nedeniyle Alman misyonerliği ve bölgede Alman menfaatlerinin temini açısından ayrı bir öneme sahip olmuştur. Bunu, Alman Sefareti'nin yetimhanenin bütün sorunlarıyla

\footnotetext{
${ }^{39}$ Feigel, a.g.e., s. 261.

40 A. von Dobbeler, a.g.m., s. 59. B. von Dobbeler, eşi ve üç çocuğu ile birlikte 17 Eylül 1919 tarihinde Haruniye'den ayrıldı. Bkz: BOA, Dâhiliye Nezâreti Emniyet-i Umûmiye Ecânib Kalemi (DH.EUM.ECB), 27/14, Lef.2.

${ }^{41}$ Feigel, a.g.e., s. 268-269.

42 Andreas Baumann, "Die Gründung des Deutschen Hilfsbund für Christliches Liebeswerk im Orient", Ernst Lohmann 1860-1936 Pioner, Gründer, Evangelist, Hrsg: Martin Knipsel, Berlin 2011, s. 61.
}

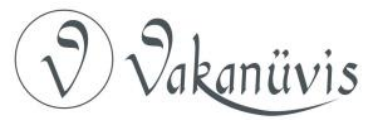


yakından ilgilenmesi ve sıkıntılı dönemlerde kurumu gözetip kollamasından anlıyoruz. Özellikle 1915 Tehcir kararıyla birlikte çoğu bölgede Ermeniler başka bölgelere nakledilmişken Alman Sefareti'nin ısrarlı talepleriyle Haruniye Yetimhanesi'ndeki Ermeni öğretmen, müstahdem ve çocuklara dokunulmamıştır.

Birinci Dünya Savaşı'nın ardından Alman misyonerler Osmanlı sınırlarını terketmek zorunda kalınca Yardım Birliği bütün istasyonlarda sorun yaşamaya başladı. Artık Anadolu topraklarında çalışamayacağını anlayan diğer bütün Batılı misyon kuruluşları gibi Alman Yardım Birliği, bakımını üstlendiği binlerce Ermeni yetimi, Amerikan Yakın Doğu Yardım Heyeti'nin himayesi altında Suriye ve Lübnan topraklarına götürmüşken Haruniye'deki yetimleri İngilizlerin kontrolü altındaki Kıbrıs'a nakletmiştir. Böylece Yardım Birliği, 1912 yılından itibaren sistemli bir şekilde faaliyet yürüttüğü yetim çalışmalarına 1920 yılında çocukların Kıbrıs'a nakledilmesiyle son vermiştir.

\section{Kaynakça}

\section{Arşiv Kaynakları}

Başbakanlık Osmanlı Arşivi (BOA)

Dâhiliye Nezâreti Emniyet-i Umûmiye Ecânib Kalemi (DH.EUM.ECB), 27/14. Dâhiliye Nezâreti İdare Evrakı (DH.ĩ), 144/44.

Dâhiliye Nezâreti İdare-i Umûmiye Evrakı (DH.i.UM), 70/20.

Dâhiliye Nezâreti Şifre Kalemi (DH.ŞFR), 52/208; 55/43; 55 A 155; 56/91; 56/157; 484/72; 491/21.

Hâriciye Nezâreti İdare (HR.iD), 83/106.

Hâriciye Nezâreti Siyasi (HR.SYS), 2438/34.

İrade Adliye ve Mezâhib (I. AZN), 105/30.

İrade Dâhiliye (I.DH), 1478/64, Lef. 2-5.

İrade Dosya Usulü (I.DUiT), 36/33.

Meclis-i Vükela Mazbataları (MV), 242/100.

\section{Salnameler}

Adana Vilayet Salnamesi 1320 (1902).

\section{Kitap ve Makaleler}

Asaf, Mehmed, 1909 Adana Ermeni Olayları ve Anılarım, Haz. İsmet Parmaksızoğlu, TTK Yay., Ankara 1986.

Baumann, Andreas, "Die Gründung des Deutschen Hilfsbund für Christliches Liebeswerk im Orient", Ernst Lohmann 1860-1936 Pioner, Gründer, Evangelist, Hrsg: Martin Knipsel, Berlin 2011, s. 48-65.

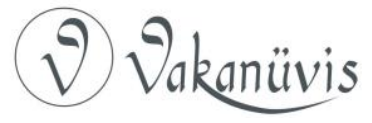


Ehmann, Johannes, "Das Waisenwerk des Deutschen Hülfsbundes im Orient", 25 Jahre im Orient Ein Gang durch die Arbeit des Deutschen Hülfsbundes für christliches Liebeswerk im Orient, Verlag Orinet, Frankfurt a. M. 1921, s. 99-109.

Feigel, Uwe, Das Evangelische Deutschland und Armenien Die Armenierhilfe deutscher evangelischer Christien seit dem Ende des 19. Jahrhunderts im Kontext der deutsch-türkischen Beziehungen, Vandenhoeck u. Ruprecht, Göttingen 1989.

İnan, Uğur, Osmanlı Devleti'nde Almanların Protestan Misyonerlik Faaliyetleri, TTK Yayınları, Ankara 2015.

Karal, Enver Ziya, Osmanlı Tarihi, Ikinci Meşrutiyet ve Birinci Dünya Savaşı, C. IX, TTK Yay., Ankara 1996.

Kieser, Hans-Lukas, Iskalanmış Barış Doğu Vilayetleri'nde Misyonerlik, Etnik Kimlik ve Devlet 1839-1938, Çev: Atilla Dirim, İletişim Yayınları, İstanbul 2010.

Meißner, Axel, Martin Rades "Christliche Welt" und Armenien: Bausteine für eine Internationale Ethik des Protestantismus, Lit Verlag, 2010 Berlin.

Okkenhaug, Inger Marie, "Women on a Mission! Scandinavian Welfare and the Armanians in the Ottoman Empire, 1905-1917", Interpreting Welfare and Relief in the Middle East, Ed: Nefissa Naguib and Inger Marie Okkenhaug, Leiden-Boston 2008, s. 57-82.

Schäfer, Richard, Geschichte der Deutschen Orient-Mission, Missionshandlung und Verlag, Lepsius, Fleischmann und Grauer, Potsdam 1932.

Shaw, Stanford J., Birinci Dünya Savaşı'nda Osmanlı ImparatorluğuErmeniler, Çev: Şadi Dinlenç, TTK Yayınları, Ankara 2017.

Shaw, Stanford J. and Ezen K. Shaw, History of the Ottoman Empire and Modern Turkey, Cambridge University Press, New York 1977.

Sommer, Ernst, "Erziehungsarbeit im Orient", 25 Jahre im Orient Ein Gang durch die Arbeit des Deutschen Hülfsbundes für christliches Liebeswerk im Orient, Verlag Orinet, Frankfurt a. M. 1921, s. 117-127.

Sonyel, Salâhi R., "İngiliz Gizli Belgelerine Göre Adana'da Vuku Bulan TürkErmeni Olayları (Temmuz 1908-Aralık 1909)", Belleten, Cilt 51, Sayı 201 (1987), s. 1241-1337.

Şişman, Adnan, XX. Yüzyılın Başlarında Osmanlı Devleti'nde Yabancı Devletlerin Kültürel ve Sosyal Müesseseleri, Atatürk Araştırma Merkezi Yayınları, Ankara 2006.

Ural, Gültekin, Ermeni Dosyası, Kamer Yayınları, İstanbul 1998.

Von Dobbeler, Anna, "Am Fuße des Amanusgebirges (Harunije)", 25 Jahre im Orient Ein Gang durch die Arbeit des Deutschen Hülfsbundes für christliches Liebeswerk im Orient, Verlag Orinet, Frankfurt a. M. 1921, s. 54-64.

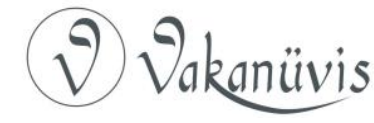




\section{EKLER}

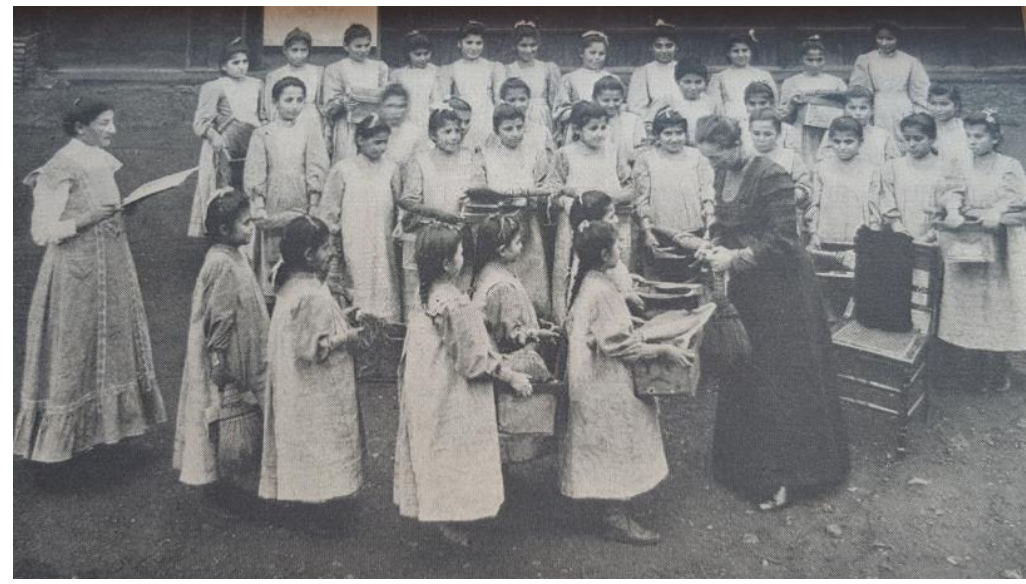

EK-1: Anna von Dobbeler Haruniye Yetimhanesi'nde kalan çocuklarla ilgilenirken.

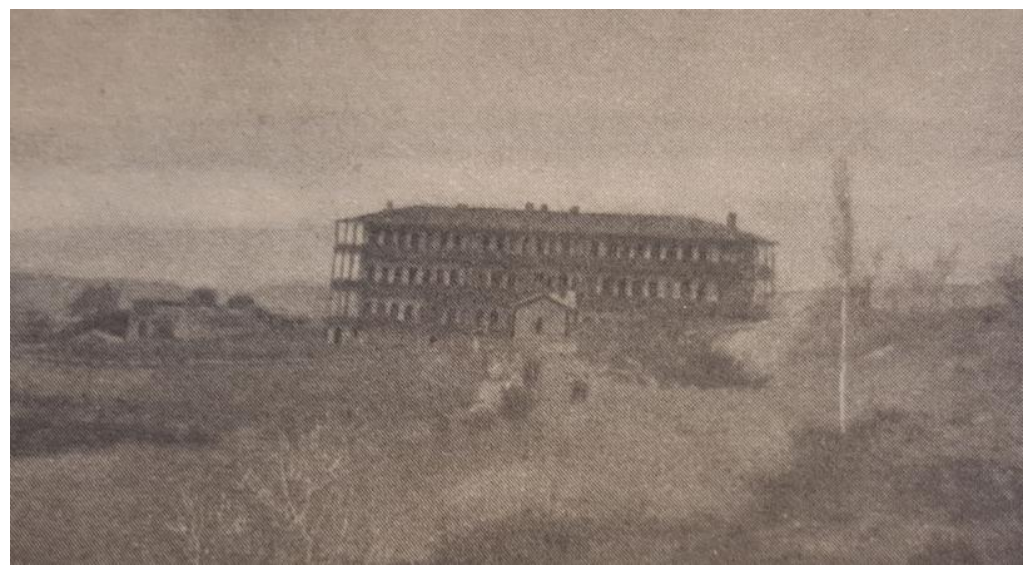

EK-2: Haruniye Yetimhanesi

Kaynak: Anna von Dobbeler, "Am Fuße des Amanusgebirges (Harunije)", 25 Jahre im Orient Ein Gang durch die Arbeit des Deutschen Hülfsbundes für christliches Liebeswerk im Orient, Verlag Orinet, Frankfurt a. M. 1921, s. 55 ve 61. 